\title{
The Influence of Microweb Public Relations Media Quality on the Image of the Ministry of Finance of the Republic of Indonesia
}

\author{
Euis Komalawati ${ }^{1}$, Kartiko Cokro Sewoyo ${ }^{2}$ \\ Stiami Institute of Social Sciences and Management, Jakarta, Indonesia
}

\begin{abstract}
The lack of standardization of website display in the scope of organizations that have many branch offices / verticals in Indonesia is still a problem and has a counterproductive effect on the image of the organization. The presence of Microweb is a solution to the problem within the Directorate General (Directorate General) of Treasury of the Ministry of Finance, this research aims to measure the influence of Microweb public relations media quality on the image of the organization. This research uses descriptive quantitative method with the population that is responsible for the public relations vertical office under the Directorate General of Treasury as the end-user who sees and operates microweb from the internal organization. Data Collection Method using questionnaires aimed at 70 samples. Sampling technique using proportional random sampling method, which then processed data using simple regression analysis. Dependent variables in this study are the image of the Directorate General of Treasury of the Ministry of Finance measured using the theory of image elements, while the independent variable is Microweb Quality as measured by the WebQual 4.0 method. Statistical results show a positive correlation between microweb quality to the image of the Directorate General of Treasury. Based on the research data, it was also concluded that the most Ability influential microweb quality indicators are Ease of Operation ( $95.7 \%$ positive response) and Visual Affairs ( $92.8 \%$ positive response), while in terms of imagery, it was concluded that respondents gave the highest value to Microweb's ability to improve the character of a professional organization (95.7\% positive response).
\end{abstract}

\begin{abstract}
ABSTRAK
Minimnya standarisasi tampilan website pada lingkup organisasi yang memiliki banyak kantor cabang / vertikal di Indonesia masih menjadi masalah dan berdampak kontraproduktif terhadap citra organisasi. Kehadiran Microweb merupakan solusi dari permasalahan di lingkungan Direktorat Jenderal (Direktorat Jenderal) Perbendaharaan Kementerian Keuangan, penelitian ini bertujuan untuk mengukur pengaruh kualitas media humas Microweb terhadap citra organisasi. Penelitian ini menggunakan metode deskriptif kuantitatif dengan populasi yang menjadi penanggung jawab kantor vertikal humas di bawah Direktorat Jenderal Perbendaharaan sebagai end-user yang melihat dan mengoperasikan microweb dari internal organisasi. Metode Pengumpulan Data menggunakan kuesioner yang ditujukan pada 70 sampel. Teknik pengambilan sampel menggunakan metode proporsional random sampling, yang kemudian diolah datanya menggunakan analisis regresi sederhana. Variabel terikat dalam penelitian ini adalah citra Direktorat Jenderal Perbendaharaan Kementerian Keuangan yang diukur
\end{abstract}

Keywords: The Quality of Public Relations Media; Microweb; Organizational Image

Kata Kunci: Kualitas Media PR; Microweb; Citra; Organisasi 
menggunakan teori elemen citra, sedangkan variabel bebasnya adalah Kualitas Microweb yang diukur dengan metode WebQual 4.0. Hasil statistik menunjukkan adanya korelasi positif antara kualitas microweb dengan citra Direktorat Jenderal Perbendaharaan. Berdasarkan data penelitian juga disimpulkan bahwa indikator kualitas microweb yang paling berpengaruh pada Ability adalah Ease of Operation (95,7\% respon positif) dan Visual Affairs (92,8\% respon positif), sedangkan dari segi pencitraan disimpulkan bahwa responden memberikan nilai tertinggi untuk kemampuan Microweb dalam meningkatkan karakter organisasi profesional (95,7\% respon positif).

\section{INTRODUCTION}

Public relations will use various media to build the reputation of the organization. One of the media that is now widely used by government public relations is the website. However, the lack of standardization of website display in the scope of organizations that have many branch offices/verticals in Indonesia is still a problem and has a counterproductive effect on the organization's image.

The website has an important role in the implementation of e-government in Indonesia. Therefore, currently, almost all government units have their websites. As shown in the table below as a retrospective, in October 2016, the Ministry of Finance ranked second in the number of website visitors that month than all ministries in Indonesia. The public's high need to access the information on the Ministry of Finance website's domain and subdomain.

Table 1. Comparison of Ministry Sites in Indonesia

\begin{tabular}{|clcccc}
\hline No & \multicolumn{1}{c}{ Ministry } & $\begin{array}{c}\text { Global } \\
\text { Rank }\end{array}$ & $\begin{array}{c}\text { Country } \\
\text { Rank }\end{array}$ & Total Visit & Avg. Visit \\
\hline $\mathbf{1}$ & Ministry of Education & 8.090 & 93 & $4,8 \mathrm{M}$ & 00.07 .31 \\
\hline $\mathbf{2}$ & Ministry of Finance & 18.294 & 231 & $2,3 \mathrm{M}$ & 00.05 .22 \\
\hline $\mathbf{3}$ & Ministry of Agriculture & 35.759 & 458 & $954.20 \mathrm{~K}$ & 00.05 .29 \\
\hline \multicolumn{6}{c}{ Source: Hernikawati (2016, p. 83) } \\
\hline
\end{tabular}

In this case, management involves building the organization's image is urgently needed, especially in the digital era. Derevianko said that the System Of Reputation Management (RMS) took place towards the gradual transfer of reputation management functions from managers to corporate stakeholders, meaning that traditional reputation management activities and company personnel were replaced by stakeholder engagement. (Derevianko, 2018). This standardization problem is also found in the Directorate General (Directorate General) of the Treasury of the Ministry of Finance. Before 2020, each vertical office under the Directorate General of Treasury independently manages the website with a free and unstandardized look and nomenclature. 
Microweb or Micro-Website is a term used by the Directorate General of Treasury in describing public relations products in the form of templates or semi-empty websites on subdomains structured in the official domain order of the Directorate General of Treasury (djpb.kemenkeu.go.id) according to the nomenclature that has been determined to replace all independent websites owned vertical offices under the Directorate General of Treasury. The term Microweb is also used to avoid confusion between the old vertical office website and the new website that has been structured under the domain djpb.kemenkeu.go.id. Microweb is also designed as a solution to the inequality of vertical office websites and meet the provisions of the Decree of the Minister of Finance (KMK) No. 458/KMK.01/2018 on Website Display Standards within the Ministry of Finance. This innovation has only begun to be implemented thoroughly in early 2020 .

In terms of content, Microweb is expected to function like an old website, providing a variety of news, regulations, the latest treasury applications, and various other services that facilitate the work of the treasurer of the Ministry's work unit while providing information for employees, communities, and academics in the vertical office area of the Directorate General of Treasury operates. The appearance of the entire Microweb is also uniformed with the main portal of the Directorate General of Treasury, including menu layout, color scheme, typography, and other matters related to website aesthetics.

Based on this question arises, whether the technical quality and display of Microweb that has been adjusted to KMK No. 458 / KMK.01 / 2018 on Website Display Standards in the Ministry of Finance has been able to replace the old website of the vertical office that is familiar in their respective working areas, as well as impacting the image of the Directorate General of Treasury of the Ministry of Finance. Studies of the website's impact on imagery show that website damage can cause significant harm to website owners through a loss of potential sales (in business) and loss of reputation, or due to legal consequences. Other research conducted in Singapore and Malaysia shown implies that both ICs in these countries rely on the precision of website functionality as a good medium to communicate with their stakeholders. (Esa \& Zahari, 2017).

The website as a communication medium is managed by the Public Relations section of an organization. Public Relations is a communication method to create a positive image of the partner organization, respecting the common interest. In government, public relations must be able to package bureaucratic and technical information to be easily digestible, thus supporting effective communication. In realizing good government public relations in the information technology industry, adaptation is needed by public relations practitioners in the government both in the means and skills needed. Therefore, many government organizations that have clusters or units or at least individuals specialized in electronic public relations (e-PR) or Cyber Public Relations (Cyber PR) activities, which according to Onggo (in Yazid, 2015) has the meaning of PR that uses the internet as a publicity media or public relations media. Government publicists have realized the 
importance of CPR. Research shows the government's public relations strategy to maintain credibility, trustworthiness, reliability, and responsibility to deliver positive news to the public internally and externally. His findings show that government public relations performed various CPR efforts and optimally utilized digital media. (Muflih \& Dany, 2019).

Public relations media is any form of media (channel) or means used by public relations practitioners in their work with the aim that the products or services marketed become better known by the. Public relations media is divided into two, namely internal and external media. According to Frank Jefkins (in Marlina et al., 2013), internal media is a form of Public Relations communication media published specifically for limited or certain circles. Another case with external media can be concluded as "All public relations activities directed to audiences outside the company". In this case, by paying attention to the audience, the website as a public relations media can act as an internal and external media.

Website is one of the applications that contain multimedia documents (text, images, sounds, animations, videos) in it that use HyperText Transfer Protocol (HTTP) and to access it using software called a browser. (Suhartanto, 2012). In practice, the main purpose of website creation in e-government is to attract users to visit and benefit as much as possible from the website in question. However, website development is often more focused on the latest aspects of technology and ignoring users' needs so that eventually, the website is not used by the targeted. (Rokhman \& Satyawan, 2012). In dealing with these problems, attention to aspects such as user characteristics (prior knowledge, behavior, gender, age), character needs or interests of users, and characteristics of the Internet system itself such as appearance, language, ease of use or ease of use, and others. (Utari, 2013). Some studies show the importance of websites in building an organization's reputation. One is a study conducted on students in Slovakia, showing a correlation of loyalty associated especially closely with reputation and satisfaction with websites. (Hacek, 2017). Various methods are carried out to analyze the website, one of which is the WebQual method.

The WebQual method is a method commonly used in measuring website quality based on user perception. This method has undergone three modifications, ranging from WebQual 1.0 to 4.0. (Lailia et al., 2018). If WebQual 1.0 focuses more on information quality analysis and tends to ignore service interactions, WebQual 2.0 instead, i.e., put more emphasis on analytics on interactions but pays less attention to information quality analysis. Webqual 3.0 came about after Barnes and Vidgen researched the quality of an online auction site and categorized quality analysis into three focus areas: Site Quality, Site Design, and Information Quality. WebQual 3.0, by changing the first dimension, namely Site Quality to Usability, gave birth to the WebQual 4.0 model (Napitupulu, 2016) The review of the website content, especially the government, has attracted attention and strengthened the significant positive influence between government pages' content on 
government institutions' reputation by netters. (Prisgunanto \& Pranawukir, 2020). Other findings suggest that interactivity, security, trust, and reputation prove to affect performance in addition to website content. Alternatively, in other words, that the quality of the web directly affects.

Studies on the influence of website content quality show: (1) The use of online and social media has a significant impact in influencing the positive image of universities (Apriananta \& Wijaya, 2018); (2) The dominant influence of Website service quality on student satisfaction is interaction quality variable (Monalisa, 2016); (3) The correlation of Study Information and Faculty News to reputation in college. The Faculty News dimension has a positive relationship with the reputation of faculty in college (Štefko et al., 2016); (4) there is a very strong relationship between XYZ university website quality evaluation and Webqual approach (Napitupulu, 2016); (5) The use of Telkomsel's website has a significant positive influence on the image of Telkomsel providers.

The studies prove that the website's quality affects the image of the organization, but the intensity of each dimension is different. The entire research above also assessed the website's quality individually, in contrast to Microweb, a public relations product consisting of a group of websites.

Therefore, although the quality of Microweb can be measured using the WebQual method, some dimensions cannot be measured because in its implementation it will differ from microweb one vertical office to another, depending on the level of activeness of the vertical office itself in updating the information (described in the next chapter).

Based on the above, his research aims to explain Microweb quality's influence on the image of the Directorate General of Treasury $n$ the Ministry of finance.

This research's Independent variable is Microweb Quality, adjusting to the WebQual 4.0 method that prioritizes user perception in assessing website quality. In contrast, the bound variable is the Image of the Directorate General of Treasury of the Ministry of Finance, measured using image elements.

Microweb Quality (Variable X) consists of two dimensions, namely Usability and Site Design. Both indicators/attributes will be described into six statements with a composition of 3-3. The image of the Directorate General of Treasury of the Ministry of Finance (Variable Y) is broken down into four dimensions, namely Personality, Reputation, Value, and Corporate Identity, and broken down into six statements.

Table 2. Variables \& Dimensions

Variable Dimensions Indicator

Usability 1. Easy to understand

2. Easy to operate 


\begin{tabular}{|c|c|c|}
\hline \multirow{2}{*}{$\begin{array}{c}\text { Microweb } \\
\text { Quality } \\
\text { (Variable X) }\end{array}$} & & 3. Easy to navigate \\
\hline & Site Design & $\begin{array}{l}\text { 1. Visually appealing design } \\
\text { 2. Innovative design } \\
\text { 3. Give a positive impression }\end{array}$ \\
\hline \multirow{4}{*}{$\begin{array}{l}\text { Image of The } \\
\text { Directorate } \\
\text { General of } \\
\text { Treasury } \\
\text { (Variable Y) }\end{array}$} & Personality & $\begin{array}{l}\text { 1. The appearance of professional } \\
\text { organizational character }\end{array}$ \\
\hline & Reputation & $\begin{array}{l}\text { 1. Fostering a sense of pride } \\
\text { 2. Pay attention to needs }\end{array}$ \\
\hline & Value & $\begin{array}{l}\text { 1. Improving understanding } \\
\text { Organizational culture }\end{array}$ \\
\hline & Corp. Identity & $\begin{array}{l}\text { 1. Improving understanding logo } \\
\text { 2. Improving vision and mission understanding }\end{array}$ \\
\hline
\end{tabular}

The two variables and their dimensions and indicators are then correlated using a framework that results in the simplification of the Theory of Stimulus Organism Response and Technology Acceptance Model as below:

Figure 1. Theoretical Framework
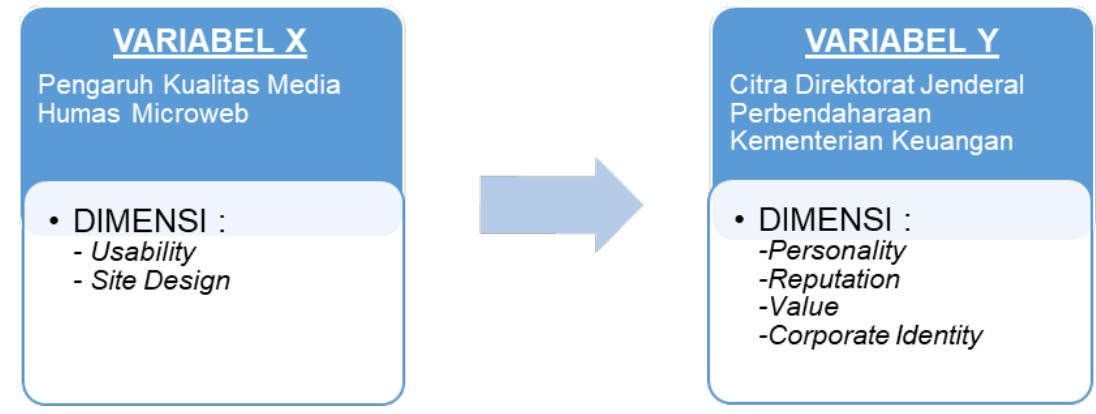

\section{METHOD}

Based on the place of implementation, this research is classified as field research or field research that appointed the Directorate General of Treasury, which is the Echelon I under the Ministry of Finance as a research subject. In terms of objectives, this research is associated with the descriptive analysis that aims to find influence between independent variables with dependent variables. (Sugiyono, 2011). Data will be obtained through the descriptive method related to the Microweb Directorate General of Treasury's quality. In contrast, associative aims to find the influence of microweb quality on the image of the Directorate General of Treasury of the Ministry of Finance. Research is also crosssectional, which is only done at a certain time, and will not be done other research at different times to be compared.

The population in this study is public relations at the Directorate General of Treasury's vertical office throughout Indonesia, which amounts to 216 people. The total population 
in this study is public relations vertical office of the Directorate General of Treasury of 216 people, so researchers use the formula, Yamane, to determine the minimum number of samples taken as follows:

$$
n=\frac{N}{N d^{2}+1}
$$

Description:

$\mathrm{n}=$ Sample Size

$\mathrm{N}=$ Population Size

$\mathrm{d}=$ Precision (Sampling Error) 10\%

Based on the Yamane formula, obtained a minimum number of samples with 10\% error tolerance, namely:

$$
n=\frac{216}{216(10 \%)^{2}+1}=68.35=69 \text { people (rounding up) }
$$

The number of samples is then divided according to the number of vertical offices of the Directorate General of Treasury per-archipelago in Indonesia, namely Sumatra, Java, Kalimantan, Bali, Nusa Tenggara (West and East), Sulawesi, Maluku (Maluku and North Maluku), and Papua (Papua and West Papua), with the following formulas and results:

$$
n i=\left(\frac{N i}{N}\right) n
$$

Description:

$\mathrm{ni}=$ number of vertical offices per archipelago

$\mathrm{n}=$ total number of samples

$\mathrm{Ni}=$ number of population members by stratum

$\mathrm{N}=$ total population

Table 3. Sample Distribution with Proportional Random Sampling Method

\begin{tabular}{|c|l|l|}
\hline No. & Islands Region & \multicolumn{1}{|c|}{ Distribution and Sample Count } \\
\hline $\mathbf{1}$ & Sumatera & $\left(\frac{59}{216}\right) 69=19$ (Rounding up) \\
\hline $\mathbf{2}$ & Jawa & $\left(\frac{65}{216}\right) 69=21$ (Rounding up) \\
\hline $\mathbf{3}$ & Kalimantan & $\left(\frac{26}{216}\right) 69=8$ (Rounding down) \\
\hline $\mathbf{4}$ & Bali & $\left(\frac{4}{216}\right) 69=1$ (Rounding down) \\
\hline $\mathbf{5}$ & Nusa Tenggara & $\left(\frac{12}{216}\right) 69=4$ (Rounding up) \\
\hline $\mathbf{6}$ & Sulawesi & $\left(\frac{31}{216}\right) 69=10$ (Rounding up) \\
\hline $\mathbf{7}$ & Maluku & $\left(\frac{8}{216}\right) 69=3$ (Rounding up) \\
\hline
\end{tabular}




\begin{tabular}{|l|l|l|}
\hline 8 & Papua & $\left(\frac{12}{216}\right) 69=4$ (Rounding up) \\
\hline \multicolumn{2}{|c|}{ Sample Total } & 70 (Rounding up) \\
\hline
\end{tabular}

\section{RESULT AND DISCUSSION}

Based on the Mean Distribution variable, $\mathrm{X}$ shows that the respondents rated microweb quality high by the respondents (total Mean value of all dimensions is worth 4.41). The two indicators with the highest Mean value are found in the Usability dimension of the $\mathrm{X} 2$ indicator and the Site Design dimension of the X4 indicator, which indicates microweb gets good value on ease of operation and visual attractiveness. (Figure 2)

Figure 2. Distribution of Mean Values in Variable X

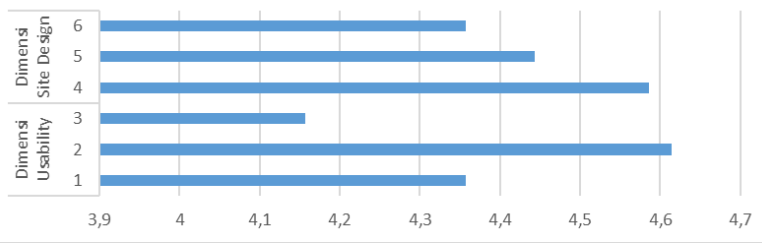

Although the value is classified as high, the lowest mean is found in the Usability dimension of the $\mathrm{X} 3$ indicator. It was found that the design has an implication minimalistic and responsive look (layout design adjusts to the tools used to access) on the Microweb implies a less consistent and less simple navigation mechanism.

As for variable $Y$, overall has a total mean of all dimensions worth 4.40 with indicators that have the highest mean value found in the Personality dimension of indicator Y1, which indicates that although designed corporate style, Microweb has successfully represented and improved the character of the Treasury As a professional bureaucratic organization (Figure 3).

Figure 3. Distribution of Mean Values in Variable $Y$

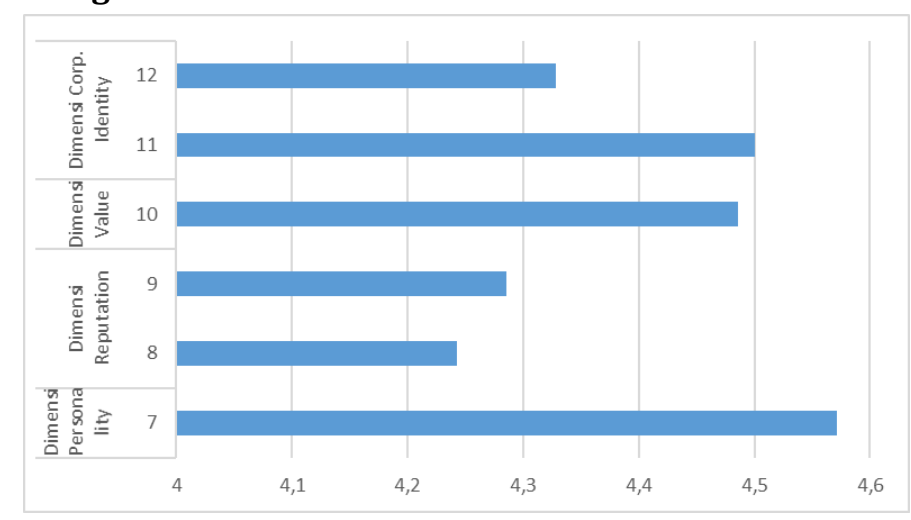

Although the value is classified as high, the two lowest mean are in the Reputation dimension, both in the Y2 and Y3 indicators. It has shown although Microweb as a public relations product can already foster a sense of pride as an employee of the Directorate 
General of Treasury and functionally can meet the needs of public relations media equivalent to the website in the vertical office, there is still room for improvement in order to achieve better results.

While the correlation coefficient analysis was conducted with the Pearson correlation test, the following results were obtained:

Figure 4. Correlation Coefficient Analysis Results

\section{Correlations}

\begin{tabular}{|c|c|c|c|}
\hline & & $\begin{array}{l}\text { Kualitas } \\
\text { Microweb } \\
(x)\end{array}$ & Citra $(\mathrm{n})$ \\
\hline \multirow{3}{*}{$\begin{array}{l}\text { Kualitas } \\
\text { Microweb }(x)\end{array}$} & Pearson Correlation & 1 & $.806^{\mathrm{kn}}$ \\
\hline & Sig. (2-tailed) & & .000 \\
\hline & $N$ & 70 & 70 \\
\hline \multirow[t]{3}{*}{ Citra (n) } & Pearson Correlation & $.806^{\star \star}$ & 1 \\
\hline & Sig. (2-tailed) & .000 & \\
\hline & $N$ & 70 & 70 \\
\hline
\end{tabular}

**. Correlation is significant at the 0.01 level (2-tailed).

The significance number is at 0.000 (below 0.05), so there is a significant relationship between variable X (Microweb Quality) and variable Y (Image of the Directorate General of Treasury). Furthermore, the correlation coefficient produces several 0.806 (Coefficient interval between 0.8 - 1.0), which, when matched with five levels of relationship according to grouping according to Sugiyono (2011), indicates that variable $\mathrm{X}$ has a very strong relationship and positive pattern to variable $Y$.

Figure 5. Results of Coefficient of Determination Analysis

\begin{tabular}{|c|c|c|c|c|}
\hline \multicolumn{5}{|c|}{ Model Summary } \\
\hline Model & $\mathrm{R}$ & R Square & $\begin{array}{l}\text { Adjusted R } \\
\text { Square }\end{array}$ & $\begin{array}{l}\text { Std. Error of } \\
\text { the Estimate }\end{array}$ \\
\hline 1 & $.806^{\mathrm{a}}$ & .650 & .645 & 1.675 \\
\hline
\end{tabular}

In this study, the coefficient of determination (R square or $\mathrm{R}^{2}$ ) was obtained worth 0.650 . Referring to the formula described in the previous chapter ( $\mathrm{kd}=\mathrm{R} 2 \times 100 \%$ ), it can be concluded that variable $\mathrm{X}$ affects the variable $\mathrm{Y}$ by $65 \%$, while the remaining $35 \%$ is influenced by other factors not studied in this study. 
Figure 6. Simple Regression Analysis Results

Coefficients $^{\mathrm{a}}$

\begin{tabular}{|c|c|c|c|c|c|c|}
\hline \multirow[b]{2}{*}{ Model } & & \multicolumn{2}{|c|}{ Unstandardized Coefficients } & \multirow{2}{*}{$\begin{array}{c}\text { Standardized } \\
\text { Coefficients } \\
\text { Beta }\end{array}$} & \multirow[b]{2}{*}{$t$} & \multirow[b]{2}{*}{ Sig. } \\
\hline & & B & Std. Error & & & \\
\hline \multirow[t]{2}{*}{1} & (Constant) & 4.727 & 1.940 & & 2.436 & .017 \\
\hline & Kualitas Microweb $(x)$ & .818 & .073 & .806 & 11.238 & .000 \\
\hline
\end{tabular}

Simple linear regression analysis produces a regression equation of $\mathrm{Y}=\mathrm{a}+\mathrm{bx}$, i.e., $Y=4,727+0.818 \mathrm{X}$. Coefficient $\mathrm{b}$ or the regression direction coefficient states that the average change of variable $Y$ for each unit of change variable $X$. positive value in coefficient $\mathrm{b}$ means the influence exerted by variable $\mathrm{X}$ to $\mathrm{Y}$ is positive. Constant 4,727 indicates that if there is no increase in variable $X$ (Microweb Quality), then the value of variable Y (Image of the Directorate General of Treasury) is 4,727.

T-Test is done to find out whether or not the effect of variable $\mathrm{X}$ on variable $\mathrm{Y}$. As seen in Figure 4, t-calculate variable $\mathrm{X}$ is 11,238 , which when compared to $\mathrm{t}$-table $(\mathrm{t}=\alpha / 2 ; \mathrm{n}-\mathrm{k}-1=$ $0.025 ; 68)$ which is worth 1,995 , then $t$-calculate greater than t-table $(11,238>1,995)$ and obtained the conclusion that $\mathrm{H}_{0}$ rejected and $\mathrm{H}_{1}$ received. (This is an influence of microweb quality on the image of the Directorate General of Treasury in the scope of the person in charge of public relations vertical office of the Directorate General of Treasury of the Ministry of Finance.)

\section{Discussion}

The results of the Mean $\mathrm{X}$ and $\mathrm{Y}$ variable distributions that have exceeded the ambivalence limit (all values show signs of approval/satisfaction above the median scale) indirectly prove the positive reaction of respondents who are representatives of the internal public population, that Microweb has been following the needs and has a strong character and can improve the positive image of the Directorate General of Treasury.

In this study, the factor that most determines the web site's quality is dominated by the ease of operation (Usability dimension). It should be underlined that in this study, the Information Quality dimension was deliberately eliminated due to microweb's unique character. Because the research is directed to the internal public (the person in charge of public relations vertical office of the Directorate General of Treasury), Microweb as a website barebone or also called only subdomains that already have a template contains a minimalist Information Quality weight (only visible in real terms on the template of the page managed by the head office, such as a page about the logo of the Directorate General of Treasury, vision-mission, and others). It is the person in charge of public relations responsible for the filling of regional-specific content, which is intended for the external public. 
However, before it can be presented to the external public, it must be ensured that Microweb has successfully met the internal needs of the organization (instead of vertical self-help websites) and get some kind of approval from the person in charge of public relations of the vertical office of the Directorate General of Treasury as the end-user (consumers who only use technology without knowing the long process behind it) who sees and operates microweb from the internal organization.

Often found websites and smartphone applications that, although it looks innovative, rarely used for various reasons such as impractical, non-user-friendly appearance, and others associated with the theory of Technology Acceptance Model (TAM) causing its users to abandon the product of the public relations. The problem is seen in Microweb, which is proven by the value of indicator 3 (ease of navigation) lower than others. It was found that the inconsistent menu and search switching mechanism due to responsive display shape (different display according to the type of device used to access) caused difficulty navigating.

However, in this research, it was obtained conclusively that Microweb Quality has a high assessment result from respondents (a total average of 4.1 out of a maximum value of 5), it becomes a kind of guarantor of the sustainability of the use of Microweb because TAM theory states that if an individual has the perception that a product in the field of technology is easy to use and has a high use value, then the individual will have the motivation to use the website repeatedly. From the suitability of tam theory, the further conclusion is drawn that Stimulus Organism Response (SOR) theory can apply positively. That is, the organism (in this case the internal public) has obtained a positive stimulus (in this case Microweb that meets the needs and has high quality) so that it can be predicted to arise a response (in this case, the use of Microweb on an ongoing basis, which implies increased user exposure to specific information from the head office of the Directorate General of Treasury, which leads to a positive assessment of the image of the Directorate General of Treasury) as well.

Variable Y, it was found that Microweb's existence supports the Directorate General of Treasury's image. In the context of the COVID-19 pandemic in the research period, Microweb becomes a crucial tool in terms of the implementation of Cyber PR as a public relations media supporting the image in the internal and external sphere of the Directorate General of Treasury.

The focus of research related to image-oriented internal public assessment is in line with Ardianto (2011), who emphasized that "It is better if the image is marketed first to employees as the main target in efforts to build an image."

Approval from the employees who in this case served as the person in charge of public relations is a kind of guarantee that the image of the Directorate General of Treasury represented through Microweb vertical office has a distinctive identity and remains 
attached to the Microweb, even after content adjustments are carried out to adjust to the needs of demographics and vertical office areas later. It can be said that Microweb strives to overcome the problem of lack of commitment of employees to the organization because of the lack of communication media and the lack of alignment of appearances both in the real world and cyberspace.

Overall, the above objectives can be said to have been achieved, seen from the average value of personality dimensions that penetrated the number 4.5. amid the demands of dynamic to the organization that often implies the emergence of an undercooked organization so that the organization seems less professional, Microweb as a public relations product can improve a professional organization's character.

The same can also be found in other indicators. Value and Corporate Identity dimensions with an average of above 4.3 prove that there is an increase in respondents' understanding of work culture, visual identity, and vision of the Mission of the Directorate General of Truth that has a further impact on the internalization of organizational values and increasing loyalty and image of the Directorate General of Treasury.

In contrast to the three dimensions in variable $Y$ above, both indicators in the reputation dimension (indicators 8 and 9) get an average below 4.3. Given that indicator eight alludes to pride as employees who tend to be more subjective and personal, respondents have more potential to choose ambivalent answers (in this case expressed with the "Disapproval" option, which ranks 3rd out of a five-rating Likert scale). Nevertheless, most respondents' answers remained on the positive spectrum, so it can be translated that Microweb's existence Microweb can support the pride as an employee of the Directorate General of Treasury.

A crucial point of the function lies in indicator 9, whether Microweb can replace the old vertical office website. As seen in the previous subsection, the results of the research showed that Microweb has been able to meet the basic needs of its manufacturing objectives, namely fulfilling the Decree of the Minister of Finance No. 458/KMK.01/2018 on Website Display Standards within the Ministry of Finance requires all to be under the domain of kemenkeu.go.id, and have a consistent display theme. However, the value that is not yet absolute is on the positive spectrum (there are still respondents who answer less agreeable) and is relatively low compared to other indicators, indicating the need for further research to identify what needs and specific areas have not-been met by Microweb.

The fulfillment of the needs represented by indicator 9 is an absolute benchmark and easy to be effective (e.g., using a checklist). Cyber PR tools are needed that, in addition to improving the image, are also able to meet the needs and improve vertical office performance, especially when associated with new remote work patterns 
(Telecommuting or Remote Work or Work from Home) during the COVID-19 pandemic that is happening when this research is conducted and will be adopted further even in the post-election period.

\section{CONCLUSION}

Based on the above research, it can be concluded that the quality of public relations media Microweb has a close relationship to the image of the Directorate General of Treasury in the scope of the person in charge of public relations vertical office of the Directorate General of Treasury of the Ministry of Finance.

Statistical results show a positive correlation between microweb quality to the image of the Directorate General of Treasury. Based on the research data also found that the most influential Microweb quality indicators are Ease of Operation (95.7\% positive response) and Visual Affairs (92.8\% positive response), while in terms of imagery, it can be concluded that although overall high value, respondents gave the highest value to Microweb's ability to improve the character of a professional organization $195.7 \%$ positive response), compared to other indicators that are the ability to accommodate different needs in each vertical office, fostering a sense of pride as an employee of the Directorate General of Treasury, improving the understanding of the organization's culture, visual identity and vision, and mission of the organization.

\section{REFERENCES}

Apriananta, Y.J., \& Wijaya, L. N. (2018). Penggunaan Website Dan Media Sosial Dalam Membangun Citra Positif Perguruan Tinggi. KOMUNIKATIF : Jurnal Ilmiah Komunikasi, 7(2), 187-209. https://doi.org/10.33508/jk.v7i2.1750

Borgolte, K., Kruegel, C., \& Vigna, G. (2015). MeerKAT: Detecting Website Defacements through Image-based Object Recognition. Proceedings of the 24th USENIX Security Symposium, 595-610.

Derevianko, 0. (2018). Stakeholder engagement to replace traditional activities in reputation management system: Insights from Ukrainian food processing companies. Problems and Perspectives in Management, 16(4), 314-330. https://doi.org/10.21511/ppm.16(4).2018.26

Esa, E., \& Zahari, A. R. (2017). Disclosure on Corporate Websites: Corporate Social Responsibility in Malaysia \& Singapore Government- Linked Companies. Journal of Technology Management and Business, 4(1), 87-95. 
Hacek, J. (2017). The correlation of usability, familiarity, satisfaction and reputation with the loyalty of student users of news websites. Medijske Studije, 8(15), 56-71. https://doi.org/10.20901/ms.8.15.5

Lailia, F., Irfan, D., \& Jaya, P. (2018). Analisis Kepuasan Pengguna Terhadap Kualitas Website SMK SMTI Padang Berdasarkan Metode Webqual 4.0. Jurnal Vokasional Teknik Elektronika \& Informatika, 6(1), 45-52.

Marlina, Tarifu, L., \& Joko. (2016). Media Humas Dalam Menjaga Citra Kantor Badan Kepegawaian Daerah (BKD) Provinsi Sulawesi Tenggara. Jurnal Ilmu Komunikasi UHO, 1(2), 1689-1699.

Monalisa, S. (2016). Analisis Kualitas Layanan Website Terhadap Kepuasan Mahasiswa dengan Penerapan Metode Webqual (Studi Kasus : UIN Suska Riau). Jurnal Sains, Teknologi Dan Industri, 13(2), 181-189.

Muflih, R., \& Dany. (2019). Strategi Government Public Relations Pusat Penerangan TNI dalam Mempertahankan Reputasi Lembaga TNI. Jurnal Komunikasi Global, 7(2), 205-216. https://doi.org/10.24815/jkg.v7i2.11979

Napitupulu, D. B. (2016). Evaluasi Kualitas Website Universitas XYZ Dengan Pendekata Webqual [Evaluation of XYZ University Website Quality Based on Webqual Approach]. Buletin Pos dan Telekomunikasi, 14(1), 51. https://doi.org/10.17933/bpostel.2016.140105

Nascimento, A. L., Sousa, J. C., Ferreira, A. V. O., Silva, K. A. F., Ferreira, A. L. C. M., Benicio, F. C., Moraes, T. A., \& Gomes, S. C. (2020). E-business, reputação corporativa e a qualidade da website como fator de desempenho empresarial. Brazilian Journal of Development, 6(4), 18546-18559. https://doi.org/10.34117/bjdv6n4-147

Prisgunanto, I., \& Pranawukir, I. (2020). Pengaruh Konten Laman Pemerintahan Terhadap Reputasi Lembaga. Jurnal Inovasi Ilmu Sosial Dan Politik, 2(2), 101-113 . https://doi.org/10.33474/jisop.v2i2.6434

Putria, N. E. (2013). Pengaruh Penggunaan Website Terhadap Citra Provider Telkomsel Batam. CBIS Journal, 1(2), 12-27.

Rokhman, A., \& Satyawan, D. S. (2012). WEB USABILITY OF PUBLIC ORGANIZATION WEBSITES: The Case of Indonesian Ministry Websites. Journal of Government and Politics, 3(2), 391-400. https://doi.org/10.18196/jgp.2012.0022

Štefko, R., Fedorko, R., \& Bačík, R. (2016). Jakość treści witryny pod względem postrzeganego wizerunku instytucji szkolnictwa wyższego. Polish Journal of 
Management Studies, 13(2), 153-163.

https://doi.org/10.17512/pjms.2016.13.2.15

Sugiyono. (2011). Metodologi Penelitian Kuantitatif Kualitatif dan R\&D. Alfabeta.

Suhartanto, M. (2012). Pembuatan Website Sekolah Menengah Pertama Negeri 3 Delanggu Dengan Menggunakan PHP Dan MySQL. Jurnal Speed - Sentra Penelitian Engineering dan Edukasi, 4(1), 1-8.

Utari, R. (2013). WEBSITE SEBAGAI MEDIA HUMAS SEKOLAH. Jurnal Penelitian Ilmu Pendidikan, 6(2), 78-87.

Yazid, T. P. (2015). Implementasi Cyber Public Relations Melalui Pengelolaan Website Pemerintah Provinsi Sumatera Barat. Jurnal Ilmu Komunikasi, 6(2), 160-173. 